\title{
MANAJEMEN KULTUR SEKOLAH (Konsep, Operasional, dan Temuan-Temuan Penelitian)
}

\author{
Roemintoyo \\ Prodi. Pendidikan Teknik Bangunan, Jurusan Pendidikan Teknik Kejuruan, FKIP, UNS \\ Kampus UNS Pabelan Jl. Ahmad Yani 200, Surakarta, Tlp (0271)718419 Fax. (0271)716266
}

\begin{abstract}
ABSTRAK
Kultur (budaya) organisasi melekat pada oganisasi. Kultur merupakan pandangan hidup yang diakui bersama oleh suatu kelompok masyarakat yang mencakup cara berfikir, perilaku, sikap, nilai yang tercermin baik dalam ujud fisik maupun abstrak. Kultur sekolah dalam suatu lingkungan pendidikan sangat dipengaruhi oleh kepemimpinan kepala sekolah. Perwujudan kultur sekolah perlu diusahakan kondisi yang mendukungnya, yaitu: kepemimpinan/keteladanan, dan bimbingan terhadap setiap anggota agar mampu meningkatkan semangat kerja dan rasa bangga akan korpnya. Nilai, moral, sikap dan perilaku siswa tumbuh berkembang selama waktu di sekolah, dan perkembangan mereka tidak dapat dihindarkan dipengaruhi oleh struktur dan kultur sekolah serta oleh interaksi mereka dengan aspek/komponen di sekolah.
\end{abstract}

Kata kunci: manajemen, kultur sekolah, konsep dan operasional.

\section{PENDAHULUAN}

Kajian tentang budaya organisasi dalam konteks manajemen pendidikan, akhir-akhir ini banyak menarik para pemerhati pendidikan maupun para peneliti. Mereka meneliti budaya organisasi dengan latar lembaga pendidikan, baik pada jenjang sekolah dasar maupun sampai dengan perguruan tinggi. Budaya organisasi yang .jelas saat ini banyak mewarnai fenomena eksistensi lembaga pendidikan.

Budaya organisasi mengacu pada suatu sistem pemaknaan bersama oleh anggota organisasi terhadap bentuk nilai, norma, keyakinan (belief), tradisi dan cara berfikir unik yang dianut, sehingga membedakan organisasi itu dengan organisasi lainnya (Robbins, 2001). Dalam konteks ini. Bondy dan Premeaux (1995) menambahkan bahwa sistem pemaknaan bersama dalam bentuk nilai, keyakinan dan kebiasaan itu berinteraksi dengan struktur formal organisasi, sehingga menghasilkan norma perilaku.

Hasil penelitian merekomendasikan adanya tujuh karakteristik utama budaya organisasi. Jika karakteristik itu dipadukan dan dipasangkan dapat menguak esensi budaya organisasi. Karakteristik budaya organisasi tersebut adalah: (1) menghargai inisiasi dan kemampuan karyawan dalam mengambil risiko: (2) mempunyai perhatian pada hal-hal kecil (attention to detail), (3) berorientasi pada hasil, (4) berorientasi ada orang), (5) berorientasi ada kerjasama tim, (6) bersifat agresif, (7) mempunyai kemantapan dalam arti menekankan perlunya mempertahankan status quo dui pada melakukan inovasi organisasi. (Robbins, 2001).

Budaya organisasi dikatakan kuat apabila nilai, sikap dan kepercayaan bersama tersebut dipahami, dianut dengan teguh, diiringi dengan komitmen yang tinggi, dan dilaksanakan, sehingga dapat menciptakan rasa kebersamaan. Kuatnya budaya organisasi dapat meningkatkan konsistensi perilaku. Sebaliknya, lemahnya budaya organisasi mullah menimbulkan kontlik Baldridge, \& Preffer, 2000). Dalam hal demikian, budaya organisasi yang kuat-ada kesamaan makna di antara sesama anggota organisasi mengenai norma, kebiasaan dan cara berfikir yang dianggap baik dalam berorganisasi dapat berperan sebagai pengganti formalisasi organisasi (Robbins, 1999).

Budaya organisasi melekat dalam suatu organisasi. Dalam organisasi apapun, baikorganisasi besar maupun organisasi kecil, di manapun atau kapanpun ditemukan budaya organisasi, termasuk dalam organisasi lembaga pendidikan sekalipun budaya organisasi hidup dan berkembang sesuai dengan karakteristik di lembaga tersebut.

Budaya sekolah dalam suatu lingkungan pendidikan sangat dipengaruhi oleh kepala sekolah. Sebagai contoh kepuasan kerja bawahan dalam hubungannya dengan pola kepemimpinan atasan dilaporkan oleh Farrow, Valensi dan Bass (1991) mereka menyimpulkan bahwa pola kepemimpinan yang melibatkan pengarahan dan delegasi memberi dampak yang lebih besar terhadap kepuasan kerja para bawahan. Oleh karena itu untuk mantapnya perwujudan budaya sekolah perlu diusahakan kondisi yang mendukungnya, diantaranya yang penting adalah: kepemimpinan /keteladanan, dan bimbingan pada setiap anggota agar mampu meningkatkan semangat kerja dan rasa bangga korpnya (Lembaga Administrasi Negara, 1994). 
Dalam makalah ini dibahas mengenai: budaya organisasi, implikasi budaya organisasi, budaya sekolah, temuan-temuan penelitian, simpulan dan saran serta lampiran dan matriks manajemen kultur sekolah.

\section{Landasan Teori}

\section{Budaya Organisasi}

1. Budaya

Menurut Kamus Besar Bahasa Indonesia (2003) yang dimaksud dengan budaya adalah (1) pikiran; akal budi, (2) adat istiadat, (3) sesuatu mengenai kebudayaan yang sudah berkembang (beradab, maju), dan (4) sesuatu yang menjadi kebiasaan yang sudah sukar diubah.

Istilah budaya pada awalnya berasal dari disiplin ilmu antropologi sosial. Apa yang tercakup dalam definisi budaya sebenarnya sangatlah luas. Budaya laksana software yang berada dalam otak manusia, yang menuntun persepsi, mengidentifikasi apa yang dilihat, mengarahkan fokus pada suatu hal, serta menghindar dan aspekaspek yang lain.

Koentjaraningrat (1989) menyebutkan unsur-unsur universal dan kebudayaan adalah (1) sistem religi dan upacara keagamaan, (2) sistem dan organisasi kemasyarakatan, (3) sistem pengetahuan, (4) bahasa, (5) kesenian, (6) sistem mata pencaharian hidup, dan (7) sistem teknologi dan peralatan. Selanjutnya dijelaskan bahwa budaya itu paling sedikit mempunyai tiga wujud, yakin kebudayaan sebagai: ( I ) suatu kompleks ide-ide, gagasan, nilai-nilai, norma-norma, peraturan dan sebagainya, (2) suatu kompleks aktivitas kelakuan dari manusia dalam masyarakat, dan (3) sebagai benda-benda karya manusia.

Wujud pertama adalah wujud ide kebudayaan yang sifatnya abstrak, tidak dapat diraba dan difoto. Lokasinya berada dalam alam pikiran dari warga masyarakat tempat kebudayaan yang bersangkutan hidup. Pada saat sekarang ini kebudayaan ide juga banyak tersimpan dalam disk, tape, arsip, koleksi microfilm dan sebagainya. Kebudayaan ide ini dapat disebut tatakelakuan, karena berfungsi sebagai tatakelakuan yang mengatur, mengendalikan, dan memberi arah kepada kelakuan dan perbuatan manusia.

Wujud kedua dari kebudayaan sering disebut sebagai sistem sosial, yang menunjuk pada perilaku yang berpola dari manusia. Sistem sosial berupa aktivitas-aktivitas rill manusia yang berinteraksi, berhubungan serta bergaul dari waktu ke waktu.
Sedangkan wujud ketiga dari kebudayaan disebut kebudayaan fisik. yaitu keseluruhan hasil aktivitas fisik, perbuatan dan karya manusia dalam masyarakat yang sifatnya kongkrit berupa benda-benda.

\section{Budaya Organisasi}

Kahan budaya organisasi claim konteks manajemen pendidikan, akhir-akhir ini banyak menarik para peneliti. Mereka meneliti budaya organisasi dengan latar lembaga pendidikan, baik di jenjang sekolah seperti sekolah menengah maupun perguruan tinggi.

Peterson (1984) Menyatakan bahwa budaya organisasi mencakup keyakinan, ideologi, bahasa, ritual dan mitos. Pendapat ini mirip dengan pendapat Owens (1991) bahwa budaya organisasi mengacu pada norma perilaku, asumsi dan keyakinan dari suatu organisasi. Sementara. Greenberg dan Baron (1995) menekankan budaya organisasi sebagai kerangka kognitif yang benisi sikap, nilai, norma perilaku dan harapan yang dimiliki oleh anggota organisasi. Sejalan dengan pendapat di atas, Soetopo (2000) menyatakan bahwa budaya organisasi berkenaan dengan keyakinan, asumsi, nilai, norma-norma perilaku, ideologi, sikap, kebiasaan dan harapan-harapan yang dimiliki oleh organisasi. Pandangan tersebut menekankan pada pendekatan karakteristik budaya dan organisasi.

Sonhadji (1991) menyatakan bahwa budaya organisasi adalah proses sosialisasi anggota organisasi untuk mengembangkan persepsi, nilai dan keyakinanan terhadap organisasi. Pendapat ini menegaskan pada faktor proses. Secara terminologi, budaya organisasi merupakan istilah yang dipergunakan untuk menjelaskan pengalaman bersama yang dialarni oleh orang-orang dalam organisasi tertentu dari lingkungan sosial mereka (Jewel \& Siegall, 1990). Ini seialan dengan pendapat Creemers \& Reynolds (1993) mengatakan bahwa budaya organisasi. Demikian pula, Schein (dalam Luthans, 1989) mengatakan bahwa budaya organisasi adalah merupakan suatu pola dasar asumsi yang ditemukan, atau dikembangkan oleh kelompok tertentu dengan mempelajari masalahmasalah yang berhubungan dengan adaptasi eksternal dan integrasi internal dimana yang melakukan pekerjaan cukup baik dianggap bernilai, dan oleh karena itu diajarkan pada anggota yang baru dengan cara yang benar untuk merasakan, memikirkan sesuatu yang berkaitan dengan masalah-masalah tersebut. Menurut Luthans (1989), budaya organisasi merupakan pola asumsi dasar yang diajarkan pada pegawai 
baru sebagai cara merasa, berpikir dan bertindak yang benar sehari-hari. Begitu pola, Kolb, Rubin \& Osland (1991) menyatakan bahwa budaya organisasi merupakan suatu pola asumsi dasar bahwa suatu kelompok telah menemukan atau mengembangkan belajar yang berhubungan dengan masalah adaptasi eksternal dan integrasi internal serta bekerja dengan cukup baik yang dianggap valid, dan oleh karena itu, diajarkan pada anggota baru sebagai cara yang benar untuk memikirkan dan merasakan hubungan dengan masalah itu. Secara skematis, budaya organisasi adalah rangkaian nilai dan norma yang mengontrol perilaku anggota organisasi dalam berinteraksi satu sama lain (Jones, 2004).

Budaya organisasi mengacu pada suatu sistem makna bersama yang dianut oleh anggotaanggota yang membedakan organisasi itu dari organisasi-organisasi lain (Robbins, 1998).

Beberapa ahli mengatakan budaya sebenarnya merupakan konsep yang dipinjam oleh pars pakar teori organisasi dari disiplin ilmu antropologi (Luthans, 1989; Gordon, 1991. Schein, 1985) mengajukan konsep budaya yang menurutnya lebih berakar pada teori-teori dinamika kelompok dan pertumbuhan kelompok daripada sekedar pada teori-teori antropologi. Selanjutnya dikemukakan oleh Schein (1985) mengajukan konsep budaya yang menurutnya lebih berakar pada teori-teori dinamika kelompok dan pertumbuhan kelompok daripada sekadar pada teori-teori antropologi.

Selanjutnya dikemukakan oleh Schein (1985) bahwa apabila kita mempelajari organisasi, kita tidak perlu membaca dan mengartikan suatu bahasa yang sama sekali asing atau seperangkat kebiasaan (customs) dan adat istiadat (mores); melainkan membeda-bedakan ciri-ciri suatu unit sosial khusus yang kita minati di dalam kerangka budaya yang lebih luas. Unit sosial ini seringkali mempunyai latar belakang sejarah yang dapat dipelajari. Lagi pula para pemeran utama yang membentuk budaya itupun dapat menjadi obyek studi. Dengan demikian, kendala yang sering dihadapi para all antropologi berupa ketiadaan data historis dapat diatasi (Indrapradja, 1992).

Berdasarkan pengamatannya, Schein (1985) mengemukakan bahwa ada beberapa pengertian yang sama yang berkaitan dengan budaya, antara lain:

1. Keteraturan perilaku yang diamati (Observed behavioral regulaties) ketika orang-orang berinteraksi, misalnya bahasa yang digunakan dan upacara-upacara yang dilakukan sehubungan dengan rasa hormat dan cara bertindak/bersikap.

2. Norma-norma yang berkembang dalam kelompok-kelompok kerja.

3. Nilai-nilai dominan yang didukung oleh sebuah organisasi, seperti mutu produk dan sebagainya.

4. Falsafah yang menjadi landasan kebijakan organisasi yang berkaitan dengan karyawan dan/atau pelanggan.

5. Peraturan-peraturan pergaulan dalam organisasi, cara-cara/seluk-beluk untuk diterima sebagai warga organisasi.

6. Rasa atau iklim yang disampaikan dalam sebuah organisasi oleh tata letak fisik

7. dan cara interaksi para warga organisasi dengan orang luar yang lain.

Berdasarkan pendapat tersebut, dapat disimpulkan bahwa budaya organisasi menunjukkan suatu nilai, norma, asumsi dan kepercayaan dalam organisasi sekolah. Dengan kata lain, budaya organisasi sekolah adalah suatu pola nilai, norma, asumsi, dan kepercayaan yang mengontrol perilaku anggota organisasi sekolah dalam berinteraksi satu dengan yang lain.

3. Karakterisik Budaya Organisasi

Karakteristik organisasi menucu pada norma pelakurut Deal \& Kennedy (dalam Abizar, 1988) mengemukakan atribut kunci budaya organisasi adalah: 1) nilai-nilai, yaitu keyakinan milik bersama dan filsafat anggotanya, 2) pahlawan organisasi/keteladanan yakni anggota organisasi yang mempunyai kepribadian terbaik dan memiliki nilai yang kuat tenang budaya organisasi, 3) ritual yakni upacara simbolik untuk merayakan dan memperkuat interpretasi nilainilai organisasi, 4) jaringan komunikasi budaya yakni saluran interaksi yang digunakan untuk memperkenalkan anggota terhadap budaya organisasi. Berbeda dengan Greenberg dan Baron (1995) yang mengemukakan ima ciri budaya organisasi yaitu: 1) kualitas (setiap orang bertanggung jawab untuk mencapai kualitas), 2) tanggung jawab (setiap pegawai bertanggung jawab atas tindakan dan keputusannya), 3) kebersamaan (menciptakan situasi dimana setiap orang bisa saling berhubungan), 4) efisiensi (keberliangsungan organisasi secara efisien), 5) kebebasan (memberi kebebasan kepada pegawai untuk merancang masa depannya). Sementara, Robbins (1988) mengemukakan bahwa ada 10 karakteristik budaya organisasi, yaitu: 1) inisiatif individu yakni kadar tanggungjawab, kebebasan, irdependesi yang dimiliki oleh individu, 2) toleransi risiko yakni kadar dorongan pegawai 
untuk agresif, inovatif, dan berani menanggung risiko, 3) diresksi yakni kadar organisasi dalam menciptakan tujuan yang jelas dan harapan kinerja, 4) integrasi yakni kadar sorongan unitunit kedalam organisasi untuk bekerja daiam suatu cara yang terkoordinasi, 5) dukungan manajemen yakni kadar manajer melakukan komunikasi yang jelas, bantuan dan dukungan pada bawahan, 6) kontrol yakni jumlah peraturan dan jumlah supervisi langsung yang digunakan untuk mengamati dan mengawasi perilaku bawahan, 7) identitas yakni kadar anggota mengidentifikasi organisasi secara keseluruhan dan pada kelompok kerja khusus atau bidang keahlian profesional, 8) sistem penghargaan yakni kadar alokasi penghargaan misalnya peningkatan gaji, promosi yang berdasarkan kriteria kinerja yang bertentangan dengan senioritas favoritisme dan lain-lain, 9) toleransi yakni kadar semangat pegawai untuk menghindari konflik dan kritik terbuka, 10) pola komunikasi yakni kadar komunikasi organisasi yang membatasi hirarki otoritas formal. Pada bagian lain. Robbins (1991) mengemukakan bahwa ada tujuan karakteristik budaya organisasi yaitu: 1) otonomi individu yakni kadar tanggung jawab, kebebasan, dan kesempatan individu untuk berinisiatif dalam organisasi, 2) struktur yakni kadar peraturan dan ketetapan yang digunakan untuk mengontrol perilaku pegawai, 3) dukungan yakni kadar bantuan dan kerarnahan manajer kepada pegawai, 4) identitas yakni kadar kenainya anggota terhadap organisasi secara keseluruhan terutama informasi kelompok kerja dan keahlian profesionalnya, 5) hadiah performansi yakni kadar alokasi hadiah yang didasarkan pada kriteria performansi pegawai, 6) toleransi konflik yakni kadar konflik dalam hubungan antar sejawat dan kemauan untuk jujur dan terbuka terhadap perbedaan, 7) toleransi resiko yakni kadar dorongan terhadap pegawai untuk agresif, inovatif dan berani menanggung resiko. Selain itu, Luthans (1989) mengatakan bahwa karakteristik budaya organisasi meliputi: 1) aturan perilaku yang dapat diamati yakni apabila peserta organisasi berinteraksi satu dengan lainnya bahasa umum yang digunakan, terminologi, language dan ritual yang berhubungan dengan perbedaan dan cara bertindak, 2) norma yakni standar perilaku yang ada yang mencakup petunjuk berapa banyak pekerjaan yang dilakukan, yang mana banyak oganisasi menunjukkan untuk tidak bekerja terlalu banyak dan tidak bekerja terlalu sedikit, 3) nilai dominan, yakni nilai-nilai utama yang dilakukan dan diharapkan oleh organisasi terhadap anggotanya untuk bekerjasama, 4) filsafat, yakni kebijakan yang menentukan keyakinan organisasi mengenai bagaimana para pekerja diperlakukan, 5) aturan, yakni berbagai petunjuk yang berlaku dalam organisasi dimana para pendatang barn harus mempelajari aturan itu agar diterima sebagai anggota tetap kelompok, 6) iklim organisasi, yakni menyangkut perasaan yang dialami secara fisik, care partisipan berinteraksi serta cara anggota organisasi berperilaku dengan orang lain. Soetopo (2000) mengambii intisari dari dua belas yakni: 1) nilai, 2) pahlawan organisasi/keteladanan, 3) tanggung jawab, 4) keintiman, 5) otonomi individu, 6) tata aturan/norma, 7) dukungan, 8) identitas, 9) hadiah performansi, 10) toleransi konflik, 11) toleransi resiko, dan 12) upacara simbolik.

Berdasarkan hal tersebut, karakteristik budaya organisasi terdiri dari: 1) nilai, 2) keteladanan, 3) tanggung jawab, 4) kebersamaan, 5) otonomi individu, 6) aturan/ norma, 7) dukungan, 8) identutas, 9) hadiah performansi, 10) toleransi konflik, 11) toleransi resiko, 12) upacara simbolik dan 13) pola komunikasi.

Robbins (1988) mengemukakan bahwa ada 10 karakteristik budaya organisasi yaitu: (1) inisiatif individu yakni kadar tanggungjawab, kebebasan, independensi yang dimiliki oleh individu, (2) toleransi resiko yakni kadar dorongan pegawai untuk agresif, inovatif, dan berani menanggung resiko, (3) direksi yakni kadar organisasi dalam menciptakan tujuan yang jelas dan harapan kinerja, (4) integrasi yakni kadar dorongan unit-unit kedalam organisasi untuk bekerja dalam suatu cara yang terkoordinasi, (5) dukungan manajemen yakni kadar manajer melakukan komunikasi yang jelas, bantuan dan dukungan ada bawahan, (6) kontrol yakni jumlah peraturan dan jumlah supervisi langsung yang digunakan untuk mengamati dan mengawasi perilaku bawahan, (7) identitas yakni kadar anggota mengidentifikasi organisasi secara keseluruhan daripada kelompok kerja khusus atau bidang keahlian profesional, (8) sistem penghargaan yakni kadar alokasi penghargaan misalnya peningkatan gaji, promosi yang berdasarkan kriteria kinerja yang bertentangan dengan senioritas favoritisme dan lain-lain, (9) toleransi konflik yakni kadar semangat pegawai untuk menghindari konflik dan kritik terbuka, (10) pola komunikasi yakni kadar komunikasi organisasi yang membatasi hirarki otoritas formal. 
Sementara itu, Luthans (1989) mengatakan bahwa karakteristik budaya organisasi meliputi: (1) aturan perilaku yang dapat diamati yakni bila peserta organisasi berinteraksi satu dengan lainnya bahasa umum yang digunakan, terminologi, language dan ritual yang berhubungan dengan perbedaan dan cara bertindak, (2) nor- ma yakni standar perilaku yang ada mencakup petunjuk berapa banyak pekerjaan yang dilakukan, yang mana banyak organisasi menunjukkan untuk tidak bekerja terlalu banyak dan tidak bekerja terlalu sedikit, (3) nilai dominan, yakni nilai-nilai utama yang dilakukan dan diharapkan oleh organisasi terhadap anggotanya untuk bekerja sama, (4) filsafat, yakni kebijakan yang menentukan keyakinan organisasi mengenai bagaimana para pekerja diperlakukan, (5) aturan, yakni berbagai petunjuk yang berlaku dalam organisasi dimana para pendatang baru harus mempelajari aturan itu agar diterima sebagai anggota tetap kelompok, (6) iklim organisasi, yakni menyangkut perasaan yang dialami secara fisik, cam partisipan berinteraksi serta cars anggota organisasi berperilaku dengan orang lain. Sedangkan Soetopo (2000) mengambil intisari dari berbagai karakteristik di atas bahwa karakteristik budaya organisasi terdiri dari dua belas yakni: (1) nilai, (2) pahlawan organisasi/keteladanan, (3) tanggung jawab, (4) keintiman, (5) otonomi individu, (6) tata aturan/norma (7) dukungan, (8) identitas, (9) hadiah performansi, toleransi konflik, (11) toleransi resiko, dan (12) upacara simbolik.

Berdasarkan hal tersebut, karakteristik budaya organisasi terdiri dari: (1) nilai, (2) keteladanan, (3) tanggung jawab, (4) kebersamaan, (5) otonomi individu. (6) aturan/norma, (7) dukungan, (8) identitas, (9) hadiah performansi, (10) toleransi konflik, (11) toleransi resiko, (12) ucapan simbolik, dan (13) pola komunikasi.

\section{Manifestasi Budaya Organisasi}

Sebagaimana dikemukakan di atas, budaya organisasi terdiri atas berbagai unsur atau elemen yang tidak semuanya dapat diamati dan diidentifikasi dengan mudah. Kotter dan Heskett (1997) peneliti dari Harvard Business School mencoba menemukan faktor-faktor mana yang membuat beberapa budaya organisasi lebih sukses dari pada yang lain. Hasil penelitiannya menunjukkan bahwa budaya mempunyai dampak yang kuat terhadap prestasi kerja. Budaya organisasi merupakan faktor yang lebih penting dalam menentukan sukses atau gagalnya suatu organisasi. Oleh karena itu, dalam studi terhadap budaya organisasi terlebih dahulu harus dikenali manifestasi budaya oganisasi.

Kotter dan Hesket (1997) mengidentifikasi bahwa budaya organisasi muncul dalam dua tingkatan, yaitu tingkatan yang tidak terlihat dan yang terlihat. Tingkatan yang tidak terlihat berupa yang dianut bersama oleh anggota kelompok cenderung bertahan meskipun anggotanya sudah berganti. Nilai-nilai ini sangat sukar untuk berubah dan anggota organisasi seringkali tidak menyadari karena banyaknya nilai. Tingkatan yang terlihat adalah berupa pola perilaku dan gaya karyawan suatu organisasi, di mana orang-orang yang baru masuk terdorong untuk mengikutinya.

Berdasarkan kenyataan di atas, maka untuk mendeskripsikan budaya suatu organisasi, pertama kali yang harus dilakukan adalah mengamati perwujudan (manifestasi) budaya tersebut, baru kemudian menangkap maknanya. Untuk itu Hodge dan Anthony (1988) rnengidentifikasi manifestasi budaya organisasi sebagai dipaparkan dalam Tabel 1 pada halaman berikut ini yang menjabarkan manifestasi budaya organisasi dan deskripsinya.

Tabel 1. Manifestasi Budaya Organisasi

\begin{tabular}{|c|l|l|}
\hline No & Manifestasi & \multicolumn{1}{|c|}{ Deskripsi } \\
\hline 1 & $\begin{array}{l}\text { Ritus (tata } \\
\text { cara upacara } \\
\text { keagamaan }\end{array}$ & $\begin{array}{l}\text { Rangkaian kegiatan yang terencana, relatif rumit dan dramatis yang } \\
\text { melibatkan berbagai bentuk ekspresi budaya dalam suatu peristiwa, yang } \\
\text { dilaksanakan melalui interaksi sosial, biasanya untuk } \\
\text { mendatangkan/kepentingan/kebaikan bagi yang hadir. }\end{array}$ \\
\hline 2 & Seremonial & Suatu sistem dari beberapa ritus yang terangkai dalam suatu peristiwa. \\
\hline 3 & $\begin{array}{l}\text { Ritual } \\
\text { (berkenaan } \\
\text { dengan ritus) }\end{array}$ & $\begin{array}{l}\text { Rangkaian teknik dan perilaku yang mendetail dan terstandar yang } \\
\text { mengelola keinginan/kegelisahan, tetapi ada kalanya menghasilkan } \\
\text { (perasaan) mendalam sebagai akibat dari hal-hal teknis yang dipentingkan } \\
\text { dalam pelaksanaan. }\end{array}$ \\
\hline 4 & Mitos & $\begin{array}{l}\text { Suatu ceritera dramatis tentang kejadian imajinasi, biasanya digunakan } \\
\text { untuk menjelaskan asal mula atau transformasi (perubahan). Atau juga suatu }\end{array}$ \\
\hline
\end{tabular}




\begin{tabular}{|c|c|c|}
\hline & & $\begin{array}{l}\text { kepercayaan yang tidak dipertanyakan tentang manfaat pelaksanaan teknik } \\
\text { atau perilaku tertentu yang tidak didukung oleh fakta yang terlihat. }\end{array}$ \\
\hline 5 & Hikayat & $\begin{array}{l}\text { Ceritera sejarah yang menggambarkan keberhasilan yang unik dari suatu } \\
\text { kelompok dan pemimpinnya. }\end{array}$ \\
\hline 6 & Legenda & $\begin{array}{l}\text { Ceritera turun temurun mengenai kejadian yang sangat hebat dan didasarkan } \\
\text { pada sejarah tetapi telah dicampuradukkan dengan kekhayalan/fiksi. }\end{array}$ \\
\hline 7 & Kisah & $\begin{array}{l}\text { Ceritera yang didasarkan atas kejadian sebenarnya tetapi sering pula } \\
\text { merupakan campuran antara kelemahan dengan khayalan. }\end{array}$ \\
\hline 8 & Dongeng rakyat & Ceritera yang sepenuhnya khayalan. \\
\hline 9 & Simbol & $\begin{array}{l}\text { Setiap obyek, tindakan, kejadian kualitas atau hubungan yang memberikan } \\
\text { sarana bagi penyampaian makna. }\end{array}$ \\
\hline 10 & Bahasa & $\begin{array}{l}\text { Salah satu bentuk atau kebiasaan dimana anggota suatu kelompok } \\
\text { menggunakan suara vokal dan tulisan untuk menyampaikan makna/maksud } \\
\text { antara satu dengan yang lain. }\end{array}$ \\
\hline 11 & Isyarat & Gerak bagian tubuh yang digunakan untuk mengekspresikan makna/maksud. \\
\hline 12 & Latar fisik & $\begin{array}{l}\text { Segala sesuatu yang mengitari orang-orang secara fisik dan dengan segera } \\
\text { memberikan rangsangan perasaan, ketika mereka melaksanakan kegiatan } \\
\text { sebagai ekspresi budaya. }\end{array}$ \\
\hline 13 & Artifak & $\begin{array}{l}\text { Obyek material (benda) yang dibuat oleh orang untuk memfasilitasi } \\
\text { pengekspresian budaya. }\end{array}$ \\
\hline
\end{tabular}

Sumber: diadopsi dari Madya Eko Susilo (2003:17) dalam bukunya "Hasil Penelitian Kualitatif Sekolah Unggul Berbasis Nilai (Studi Multi Kasus di: SMA Negeri 1, SMA Regina Pacis, SMA Al Islam 01 Surakarta. Sukoharjo: Univet Bantam Press.

\section{A. Implikasi Budaya Organisasi}

1. Budaya organisasi yang Berhasil

Penelitian menunjukkan bahwa budaya organisasi berkaitan dengan keberhasilan organisasi. Seperti terlibat pada Gambar 1, budaya yang berdasarkan kepada kemampuan menyesusaikan diri, keterlibatan, misi yang jelas, dan kemantapan, dapat membantu suatu perusahaan mencapai pertumbuhan penjualan, pengembalian modal, keuntungan, mutu, dan kepuasan karyawan yang lebih tinggi.

Kemampuan menyesuaikan diri adalah kemampuan untuk mengenali dan menanggapi perubahan lingkungan organisasi. Pada budaya yang mendorong tingkat keterlibatan karyawan lebih tinggi dalam pengambilan keputusan, karyawan akan memiliki rasa kepemilikan dan tanggungjawab yang lebih besar.

Visi suatu lembaga adalah maksud atau alasan mengapa didirikan. Di dalam budaya organisasi di mana terdapat visi organisasi yang jelas, tujuan, dan arah strategis organisasi terlihat jelas bagi setiap orang di dalam lembaga tersebut. Dan ketika pimpinan (manajer) merasa tidak pasti akan lingkungan usaha mereka, visi tersebut membantu mengarahkan diskusi, keputusan, dan perilaku karyawan di dalam lembaga. Akhirnya, dalam budaya organisasi yang konsisten, perusahaan dengan aktif menguraikan dan mengajarkan nilai-nilai, keyakinan, dan sikap organisasi. Budaya organisasi yang konsisten juga disebut budaya kuat, karena keyakinan utama dimiliki dan dihayati bersama dengan kuat.

2. $\begin{aligned} & \text { Beberapa Kajian Tentang Budaya } \\ & \text { Organisasi }\end{aligned}$

Hasil penelitian Ouchi yang diterbitkan pada tahun 1981 mengenai budaya organisasi telah mengejutkan berbagai pihak yang telah lama terpaku dengan penelitian sebelumnya. Temuan Ouchi dipublikasikan ketika para manajer operasional perusahaan Amerika berusaha memecahkan persoalan mereka dalam pertemuan kompetisi dengan masyarakat Jepang. Ouchi, warga Amerika keturunan Jepang membandingkan dan mengontraskan gaya manajemen yang dilakukan oleh kedua bangsa Amerika dan Jepang. Ouchi menemukan bahwa praktik manajemen Jepang cenderung berbeda dan beberapa gaya manajemen tersebut dapat diadopsi oleh organisasi Amerika.(Owens, 1995).

Teori Ouchi tentang budaya organisasi mengevaluasi teori $\mathrm{X}$ dan $\mathrm{Y}$ karya Douglas McGregor. Menurut teori $\mathrm{X}$, manusia pada dasarnya tidak mau bekerja dan cenderung menghindari tanggung jawab. Oleh karena itu, manusia harus diarahkan dan dikontrol supaya 
man bekerja. Filosofi teori ini adalah manusia harus dimotivasi dengan uang, tunjangan tambahan, dan perlu diberi hukuman (Hersey \& Blanchard, 1978). Sebaliknya teori Y menyebutkan bahwa pada dasarnya manusia senang bekerja keras dan menerima tanggung jawab. Menurut teori ini manusia menganggap bahwa bekerja bersifat alami dan mendatangkan kepuasan bagi dirinya.

Berangkat dad hasil evaluasi teori $X$ dan $\mathrm{Y}$, Ouchi menawarkan nama teori $\mathrm{Z}$ sebagai alternatif. Teori $\mathrm{Z}$ menyatakan bahwa kondisi kerja manusia tidak hanya meningkatkan produktivitas, tetapi juga meningkatkan kepercayaan diri (self esteem) bagi pegawai. Sampai saat ini sebagian para manajer organisasi mempunyai asumsi bahwa teknologi meningkatkan produktivitas kerja. Teori Z menyarankan bahwa manajer perlu mengarahkan kembali perhatian kepada hubungan manusiawi yang lebih humanstik di dalam organisasi (Ouchi, 1981 \& Owens, 1995). Lebih lanjut, Ouchi menyatakan bawa untuk mencapai keberhasilan dalam suatu organisasi perlu dikembangkan kepercayaan, nilai, norma, asumsi dasar, tradisi-tradisi, dan kebiasaan yang unik dari suatu organisasi. Menurut Ouchi ada tiga syarat kunci untuk mengembangkan budaya organisasi, yaitu (1) adanya saling percaya (trust), (2) kehalusan (subtlety), dan (3) kearaban (intimacy).

3. Perilaku Sebagai Wujud Budaya Organisasi

Sesuai dengan wujudnya, kebudayaan dapat dibagi dalam tiga wujud, yaitu (1) artifact atau benda-benda fisik hash kecerdasan, (2) tingkah laku berpola, (3) kebudayaan sebagai sistem gagasan (Koentjaraningrat, 1996). Berdasarkan pendapat tersebut, maka dapat dikemukakan bahwa budaya organisasi termasuk ada wujud budaya yang kedua yaitu tingkah laku berpola.

Untuk memudahkan pemahaman tentang perilaku berpola, dan melihat gejalagejala yang ada dalam suatu organisasi, digunakan suatu model. Model ialah suatu representasi konsep yang lebih tinggi yang berguna untuk memudahkan pengungkapan suatu gejala-phenomenon-dan meningkatkan pemahaman kita mengenai fenomena itu (Hoy dan Miskel, 1978). Lebih lanjut dijelaskan bahwa model juga berguna membantu pikiran kita untuk masuk ke dalam hakikat perilaku yang menjadi bagian dari budaya organisasi; mempermudah melakukan analisis konsep dan simbol-simbol, dan memberi sinyal tentang kesamaan dan perbedaan komponen-komponen dalam organisasi termasuk organisasi pendidikan.

Salah satu model yang dapat digunakan untuk memahami perilaku berpola adalah model Getzels dan Guba yang melihat perilaku dalam organisasi sebagai suatu sistem sosial (Owens, 1991). Istilah perilaku sebagai sistem sosial juga dikemukakan oleh Koentjaraningrat (1996) yaitu semua gerak-gerik yang dilakukan dari saat ke saat, dan dari hari ke hari, dari masa ke masa merupakan pola tingkah laku yang dilakukan berdasarkan sistem. Oleh karena itu, pola-pola tingkah laku manusia di dalam organisasi disebut sistem sosial.

Perilaku sosial dalam organisasi menurut konsep awal Getzeld dan Guba ditentukan oleh dua dimensi, yaitu dimensi nomothetic (dimensi institusi) dan dimensi idiographic (dimensi kepribadian). Kemudian dikembangkan menjadi lima dimensi dengan cara memasukkan dimensi budaya (antropologi), dimensi iklim, organisasi, dan diners; biologis (Owens, 1991).

Interaksi timbal balik antara ke lima dimensi itu (dimensi nomothetic, idiograpic, antropologi, iklim organisasi dan dimensi biologis) disajikan dalam bentuk sistem terbuka dan mempunyai pengaruh terhadap perilaku kepemimpinan, perilaku anggota dan merupakan milik organisasi.

\section{B. Budaya Sekolah}

Sekolah sebagai suatu sistem memiliki tiga aspek pokok yang sangat berkaitan erat dengan mutu sekolah, yakni: proses belajar mengajar, kepemimpinan dan manajemen sekolah, serta kultur sekolah.

Dalam menjalankan tugas dan fungsinya, Kepala Sekolah harus memahami kultur atau budaya sekolah yang dipimpinnya. Kultur sekolah ini berkaitan erat dengan misi yang dimiliki oleh Kepala Sekolah tentang masa dean sekolah. Kepala Sekolah yang memiliki visi untuk menghadapi tantangan sekolah di masa dean akan lebih sukses dalam membangun sekolah. Oleh karma itu, Kepala Sekolah harus memiliki budaya kerja (kebiasaan bekerja).

1. Budaya Sekolah sebagai Organisasi

Dalam kaitannya dengan pembahasan budaya sekolah sebagai organisasi, Robbins (1983) mengemukakan bahwa setiap organisasi mempunyai budaya tersendiri yang unik. Termasuk dalam pembahasan ini adalah organisasi yang berbentuk sekolah. Selanjutnya dijelaskan oleh Robbins (1983) bahwa budaya 
tersebut telah ada sejak organisasi itu sendiri dan biasanya berupa aturan penyeimbang yang tidak tertulis, mempunyai bahasa tersendiri dalam menjembatani komunikasi antara anggota, adanya standarisasi aspek kerja yang telah dilakukan, standar yang berlaku didalam etika dan bertingkah laku, penentuan kebiasaan membina hubungan seorang anggota dengan teman sebayanya, bawahan atasan dan pihak War, dan kebiasaan lain yang disesuaikan dengan kebiasaan pada umumnya dan tindakan yang cukup pandai didalam kerja organisasi dan tindakan yang tidak perlu dilakukan.

Berdasarkan konsep budaya organisasi seperti yang dikemukakan oleh Robbins (1983) tersebut di atas, apabila ditelaah lebih rind, ada beberapa unsur yang terkandung dalam budaya organisasi antara lain dapat disebutkan sebagai berikut :

- adanya aturan penyeimbang yang tidak tertulis,

- mempunyai bahasa sendiri dalam menjembatani komunikasi, standarisasi aspek kerja yang berlaku,

- standar yang beriaku didalam etika dan bertingkah laku,

- penentuan kebiasaan membina hubungan seorang anggota dengan teman

- sebayanya, bawahan, atasan dan pihak luar, dan

- kebiasaan lain yang disesuaikan dengan kebiasaan pada umumnya.

- Unsur-unsur tersebut di atas apabila diterapkan di lingkungan sekolah banyak sekali persamaannya, antara lain adanya tata tertib di sekolah, dan sebagainya. Yang kesemuanya itu membentuk budaya suatu organisasi sekolah.

Secara lebih khusus perihal gambaran karakter-karakter dari suatu budaya yang dapat diidentifikasi oleh para peneliti antara lain adalah mencakup unsur-unsur sebagai berikut :

1. Hak otonomi indvidu, yaitu adanya tingkatan tanggung jawab, kemandirian dan kesemnatan untuk melatih inisiatif individu dalam bertindak secara organisasi.

2. Struktur, yaitu adanya tingkatan aturan penyeimbang dan sejumlah pengawasan yang digunakan untuk mengontrol kinerja para karyawan.

3. Dukungan, yaitu adanya tingkatan dimana individu mengelompokkan organisasi sebagai organisasi khusus atau kelompok staf ahli.
4. Identifikasi, yaitu adanya tingkatan dimana individu mengelompokkan organisasinya sebagai organisasi khusus atau kelompok staf ahli.

5. Penghargaan performansi, yaitu adanya tingkatan pemberian penghargaan didalam organisasi (misalnya: peningkatan gaji, promosi) yang didasarkan atas kriteria performansi karyawan).

6. Toleransi (pemecahan) konflik, adanya tingkatan konflik yang terjadi pada hubungan antara personil atau kelompok kerja dipandang sebagai keinginan untuk menyelaraskan perbedaan yang timbul.

7. Pemecahan resiko, adanya keinginan karyawan untuk memberikan dukungan agar iebih inovatif, bersemangat dan tanggap akan resiko yang timbul. (Robbins, 1983).

Masing-masing karakteristik tersebut di atas merupakan satu rangkaian kesatuan yang berkesinambungan. Melalui penilaian pada tujuh karakteristik ini, penyatuan gambaran mengenai pengaturan ciri budaya terbentuk.

Apabila ketujuh ciri karakteristik tersebut diaplikasikan dalam organisasi sekolah, maka sebenarnya tidak jauh berbeda. Karena kalau dirinci ketujuh karakteristik budaya tersebut pada hakekatnya ada dalam setiap organisasi pendidikan yang berbentuk sekolah. Budaya organisasi tersebut akan banyak mempengaruhi perilaku individu yang berada didalamnya. Yang lebih penting lagi, bahwasanya apakah perilaku individu dalam kelornpok tersebut sesuai dengan budaya organisasi, yaitu mengetahui tata tertib, norma, aturan dan kebiasaan yang berlaku dalam organisasi tersebut. Dalam kenyataannya setiap sekolah mempunyai budaya yang berbeda dengan seklah yang lain, hal ini dikarenakan latar budaya, geografis, norma-norma dan kebiasaan yang berlaku di suatu sekolah berbeda antara satu dengan lainnya.

Berdasarkan pendapat Robbins di atas, jelas ditunjukkan bahwa indikator-indikator yang dijadikan tolok ukur suatu budaya organisasi adalah otonomi individual, struktur organisasi, dukungan, identitas organisasi, insentif kinerja, toleransi konflik dan toleransi resiko. Semua indikator budaya organisasi tersebut selanjutnya memberikan imbas terhadap iklim kerja atau budaya kerja.

2. Sekolah dan Hakekat Perubahan

Pada hakekatnya sekolah harus rnenyesuaikan dengan lingkungannya yang terus menerus berubah dari waktu ke waktu. Hal ini 
memberikan gambaran komitmen sekolah sebagai agen perubahan.

a. Hakekat Perubahan

Pada era globaliasi saat ini segala sesuatu akan berubah sedemikian cepat. Demikian cepat perubahan itu berlangsung sehingga masyarakat tidak sadar bahwa din mereka sendiri yang telah berubah. Dinamika perubahan masyarakat yang cepat tersebut menuntut sekolah harus memiliki fleksibilitas untuk dapat memenuhi tuntutan siswa dan masyarakat. Pendidikan sebagai proses untuk mempersiapkan anak untuk bisa hidup layak di masa depan. Namun, masa depan itu sendiri terus berubah tidak sebagaimana yang terjadi pada masa kini. Oleh karena itu, kurikulum pendidikan harus bersifat lebih fleksibel, dan membekali siswa dengan kemampuan untuk melakukan transformasi ilmu pengetahuan dan keterampilan agar dapat dipergunakan dalam berbagai bidang yang berbeda. Terutama kurikulum yang dapat mengantisipasi perubahan yang diakibatkan oleh pesatnya perkembangan ilmu pengetahuan dan teknologi.

Kecepatan perubahan juga akan menyebabkan ilmu pengetahuan akan berkembang sangat cepat. Kebenaran hari ini belum tentu benar untuk hari esok. Sebagai konsekuensinya, semua unsur dalam sekolah harus selalu meningkatkan pengetahuan dan kemampuannya masing-masing. Semua unsur sekolah harus senantiasa memperbaharui ilmu dan pengetahuannya. Oleh karena itu, di sekolah harus dikembangkan kultur yang mendukung belajar keras, disiplin, jujur, mandiri dan kreatif, disamping dilatih "learning how to learn".b

b. Faktor Pembentuk Kultur Sekolah

Nilai, moral, sikap dan perilaku siswa tumbuh berkembang selama waktu di sekolah, dale perkembangan mereka tidak dapat dihin ${ }^{\mathrm{d}}$ arkan dipengaruhi oleh struktur dan kultur sekolah, serta oleh interaksi mereka dengan aspek-aspek dan komponen yang ada di sekolah, seperti kepala sekolah, guru, materi pelajaran, dan antar siswa sendiri.

\section{c. Teori Pembelajaran Menurut Siswa}

Untuk mengembangkan kultur sekolah, guru juga harus memahami kemauan dan keinginan siswa. Keinginan siswa tidaklah muluk-muluk. Mereka antara lain mendambakan guru yang (1) ingat bahwa siswa belajar dengan gaya yang berbeda. Metode mengajar harus disesuaikan dengan realitas ini, (2) tidak menakut-nakuti dan membikin malu siswa dalam belajar, (3) bertindak adil tanpa memandang latar beiakang siswa, (4) memotivasi siswa untuk bekerja keras dengan contoh, tidak hanya dengan perintah, dan (5) mengembangkan kebanggaan pada diri siswa atas prestasi yang dicapai.

d. Faktor Penentu Perubahan

Untuk menciptakan perubahan kultur sekolah, tahap-tahap yang harus dilalui, mencakup: (1) ada kebersamaan perhatian diantara warga sekolah, (2) mempererat kebersamaan diantara warga sekolah, (3) mengkaji problema dalam perubahan, (4) mencari solusi atas problem, (5) mengkaji lebih mendalam alternatif solusi yang ada dan mencobanya, (6) memperluas pelaksanaan uji coba solusi dalam ruang lingkup yang lebih luas, dan (7) memulai proses pembaharuan.

Kepala sekolah dalam mengarahkan dan menggerakkan perubahan perlu memahami bahwa: (1) penentu keberhasilan bukan saja karena keberadaan seorang pemimpin yang punya visi, tetapi juga keberadaan seseorang yang senantiasa bersedia membantu orang lain ikut merencanakan dan mengimplementasikan perubahan, (2) perubahan hanya akan dilakukan manakala arah perubahan sesuai dengan value dan nilai-nilai yang dipegang bersama, (3) isi perubahan harus jelas, pemimpin harus dapat merumuskan apa yang akan dilakukan di masa depan, (4) keberadaan dan kerjasama harus dikembangkan di kalangan warga sekolah, (5) kerjasama dan kebersamaan memerlukan komunikasi yang efektif diantara warga yang terlibat dalam perubahan, (6) dorongan dan semangat harus selalu dikembangkan dikalangan warga sekolah, (7) pelaksanaan perubahan harus senantiasa setia terhadap tujuan dan program pembaharuan di sepanjang waktu, (8) proses perubahan harus diiringi dengan umpan balik, resistensi terhadap perubahan adalah normal, tetapi resistensi yang berlebihan perlu dicermati, dan (9) pemimpin harus berani menegur pada saat diperlukan, terutama menegur bagi siapa saja yang menentang adanya perubahan.

Budaya sekolah dalam suatu lingkungan pendidikan sangat dipengaruhi oleh kepemimpinan kepala sekolah. Sebagai contoh kepuasan kerja bawahan dalam hubungannya dengan pola kepemimpinan atasan dilaporkan oleh Farrow, Valensi, dan Bass (dalam Mantja, 1991). Ketiganya menyimpulkan bahwa pola kepemimpinan yang melibatkan pengarahan dan delegasi memberikan dampak yang lebih besar terhadap kepuasan kerja para bawahan. Oleh karena itu, untuk mantapnya perwujudan budaya 
sekolah diperlukan seorang pemimpin atau kepala sekolah yang dapat menerapkan kepemimpinan yang memberdayakan potensi sumber daya yang ada.

Uraian singkat tersebut di atas, semakin mengukuhkan pendapat bahwa keberadaan kepala sekolah dengan pola perilaku serta modal kepemimpinannya sangat mempengaruhi budaya sekolah yang menjadi wewenang dan tanggung jawabnya.

\section{PEMBAHASAN}

Banyak para peneliti tertarik mengkaji lebih mendalam tentang budaya dalam organisasi (khususnya pendidikan). Beberapa peneliti tersebut antara lain sebagai herikut ini.

Soetopo (2001) dalam penelitiannya (disertasi) dengan judul "Hubungan Karakteristik Bawahan, Kontrol Situasi, Perilaku Kepemimpinan, Budaya Organisasi, dan Iklim Organisasi dengan Keefektifan Organisasi pada Universitas Swasta di Kotamadya Malang". Hasil penelitiannya tentang budaya organisasi menunjukkan bahwa (1) makin tinggi karakteristik bawahan yang mencakup kematangan, lokus kontrol, kemampuan melaksanakan tugas, kebutuhan, pengalaman, dan kesiapan menerima tanggungjawab tidak dikuti makin tingginya perilaku kepemimpinan yang berorientasi pada hubungan antar manusia, (2) makin tinggi kontrol situasi yang terdiri atas hubungan pemimpin-bawahan, struktur tugas, dan posisi kekuasan diikuti makin tingginya perilaku kepemimpinan yang berorientasi pada hubungan antar manusia; (3) makin tinggi orientasi kepemimpinan pada hubungan antar manusia diikuti makin kuatnya budaya organisasi dan makin efektifnya organisasi, (4) makin tingginya orientasi pemimpin pada hubungan antar manusia tidak diikuti makin terbukanya iklim organisasi, (5) makin tingginya orientasi pemimpin pada hubungan antar manusia diikuti makin terbukanya iklim organisasi asalkan disertai dengan budaya organisasi yang kuat, (6) makin kuatnya budaya organisasi diikuti makin terbukanya iklim organisasi dan makin efektifnya organisasi, (7) makin tingginya perilaku kepemimpinan berorientasi pada hubungan antar manusia tidak diikuti makin efektifnya organisasi setelah disertai dengan iklim organisasi yang terbuka, dan (8) makin kuatnya budaya organisasi diikuti makin efektifnya organisasi asalkan disertai iklim organisasi yang terbuka.
Hariyanto (2002) dalam penelitiannya (tesis) yang berjudul "Kontribusi Kinerja Kepala Sekolah dan Budaya Sekolah terhadap Kinerja Guru SLTP Negeri di Kabupaten Malang." Berdasarkan hasil analisis ditemukan bahwa: (1) sebagian besar responden $(58,87 \%)$ atau 146 responden memberikan jawaban tentang kinerja Kepala Sekolah SLTP Negeri di Kabupaten Malang berkualifikasi tinggi, (2) sebagian besar responden $(68,15 \%)$ atau 169 responden guru memberikan jawaban tentang budaya sekolah SLTP Negeri di Kabupaten Malang berkualifikasi tinggi, (3) sebagian besar responden guru $(45,16 \%)$ atau 112 responden memberikan jawaban tentang kinerja guru berkualifikasi sedang, (4) kinerja Kepala Sekolah memiliki kontribusi yang sangat meyakinkan terhadap kinerja guru SLTP Negeri di Kabupaten Malang dengan harga $\mathrm{T}=7,909$ dengan signifikansi $\mathrm{T}=0,0000$ atau $0 \%$, (5) budaya sekolah memiliki kontribusi terhadap kinerja guru SLTP Negeri di Kabupaten Malang dengan harga $\mathrm{T}=3,282$ dengan signifikansi $\mathrm{T}=$ 0,0012 atau $0,12 \%$, dan (6) secara simultan kinerja Kepala Sekolah dan budaya sekolah ternyata memiliki kontribusi terhadap Kinerja Guru Negeri di Kabupaten Malang dengan harga $\mathrm{F}=154,93523$ dengan signifikansi $\mathrm{T}=0,0000$ atau $0 \%$.

Salfen (2002) dalam penelitian disertasinya yang berjudul "Budaya Organisasi Perguruan Tinggi: Studi di Sekolah Tinggi Ilmu Ekonomi (STIE) "Abdi Bangsa Indonesia", mengemukakan temuan penelitian bahwa: (1) terbentuknya budaya organisasi tidak terlepas dari peran pimpinan organisasi. Sementara itu, nilai yang dikembangkan dan diterapkan sejak dini adalah kejujuran, keadilan dan tanggung jawab; (2) wujud budaya yang dirasakan oleh anggota organisasi adalah kualitas, didukung oleh budaya kekeluargaan dan kebersamaan yang dilandasi sikap manusiawi suka menolong. Budaya kualitas didukung oleh semua unsur organisasi baik yang tampak (tangible) maupun yang tidak tampak (intangible) antara lain pernyataan visi misi organisasi, nilai organisasi, fasilitas fisik, ruangan dan mebeler, proses belajar mengajar, perpustakaan, teknologi, dosen yang bermutu, praktik manajemen dan akuntansi serta pelatihan bahasa Inggris, Mandarin dan Jepang; (3) wujud budaya direkat oleh adanya rasa saling percaya, keakraban, jujur dan bertanggung jawab terhadap pekerjaan. Semua itu tidak terlepas dari terintemalisasinya nilainilai organisasi dan filosofi ke dalam hati 
sanubari anggota organisasi, sehingga nilai dan filosofi organisasi telah menjadi strategi dan keunggulan organisasi; (4) terinternalisasinya nilai dan filosofi organisasi tersebut menciptakan iklim organisasi yang kondusif dan bermuara pada keefektifan organisasi. Kepatuhan dan ketidakpatuhan anggota organisasi terkait pula dengan internalisasi nilai organisasi. Namun demikian internalisasi niai dapat pula menjadi kendala budaya organisasi, karena nilai yang terinternalisasi membuat karyawan menjadi patuh dan loyal kepada organisasi, dan adakalanya kepatuhan dan loyalitas tersebut lebih mengarah kepada pribadi pimpinan, akibatnya karyawan yang patuh dan loyal tersebut menggunakan berbagai cara untuk dapat "dekat" dengan pimpinan, dan anggota organisasi dijejali dengan tugas-tugas yang banyak tanpa diimbangi dengan reward yang wajar. Kebiasaan yang ada pun memberatkan karyawan karena karyawan yang patuh diberi tugas terus-menerus, tanpa mempertimbangkan deskripsi pekerjaan. Implikasi penelitian ini adalah lembaga pendidikan tinggi perlu membentuk budaya organisasi sebagai bagian dari strategi dan keunggulan organisasi. Apalagi jika dikaitkan dengan kondisi bangsa yang terpuruk karena kurangnya perhatian terhadap nilai kejujuran, keadilan dan tanggung jawab dalam semua strata dan kehidupan bermasyarakat.

Gemnafle (2003) dalam penelitian kuantitatif disertasinya yang berjudul "Hubungan Budaya Organisasi, Keterampilan Manajerial Kepala Sekolah dan Pelaksanaan Pengawasan dengan Kinerja Guru dalam Mengajar di SMU Negeri dan Swasta di Sulawesi Tenggara." Hasil penelitiannya menunjukkan bahwa pada umumnya terdapat hubungan kausal langsung dan tak langsung yang signifikan antara budaya organisasi dengan keterampilan manajerial, budaya organisasi dengan pelaksanaan fungsi pengawasan, budaya organisasi dengan kinerja guru dalam mengajar melalui pelaksanaan fungsi pengawasan, keterampilan manajerial dengan fungsi pengawasan, keterampilan manajerial dengan kinerja guru dalam mengajar, keterampilan manajerial dengan kinerja guru dalam mengajar melalui pelaksanaan fungsi pengawasan, pelaksanaan fungsi pengawasan dengan kinerja guru dalam mengajar, budaya organisasi dan keterampilan manajerial dengan kinerja guru dalam mengajar melalui pelaksanaan fungsi pengawasan. Sejalan dengan basil penelitian yang dikemukakan di atas, maka diajukan beberapa saran sebagai berikut: (1) para pengelola pendidikan, baik tingkat Propinsi maupun Kabupaten/Kota, (2) Para Kepala SMU perlu mengefektifkan fungsi-fungsi manajemen dalam kepemimpinannya, khususnya fungsi pengawasan untuk mengefektifkan kinerja guru dalam mengajar.

Ekosusilo (2003) dalam penelitian kualitatif disertasinya yang berjudul "Sekolah Unggul Berbasis Nilai (Studi Multi Ksus di SMA Negeri 1, SMA Regina Pacis, dan SMA Al Islam 01 Surakarta). Berdasarkan penelitiannya, maka dapat diketahui temuantemuan penelitiannya sebagai berikut: Pertama, karakteristik budaya organisasi sekolah di masing-masing memiliki andil yang besar dalam membentuk sistem nilai dalam budaya organisasi sekolah, (2) karakteristik budaya organisasi sekolah pada SMU Negeri 1, Surakarta meliputi: (a) sejarah yang panjang, (b) input siswa maupun guru yang terseleksi, dan (c) besarnya dukungan dari pemerintah, (3) karakteristik budaya organisasi sekolah pada SMU Regina Pacis Surakarta, meliputi: (a) karya Biara Ursulin, (b) lingkungan fisik dan sarana sekolah "sangat baik" dibanding sekolah lainnya, bentuk bangunannya mengikuti standar sekolah di Eropa dan dipengaruhi oleh arsitektur Belanda, karena para perintis sekolah ini para Suster Ursulin yang memiliki jaringan internasional, (c) latar belakang siswa berasal dari etnis dan agama yang beragam, (d) kedisiplinan dan tata tertib ketat, (e) program bimbingan dan konseling intensif, serta adanya program layanan puma studi untuk memberikan kemudahan para lulusan dalam memperoleh akses masuk ke Perguruan Tinggi, baik di dalam maupun di luar negeri, dan (f) adanya kelompok kegiatan pendalaman spiritualitas,

Karakteristik budaya organisasi sekolah pada SMU Al Islam I Surakarta terlihat pada (a) homogenitas latar belakang siswa, khususnya dari segi agama; (b) libur hari Jumat; (c) keterpaduan pelajaran Agama Islam dengan mata pelajaran umum; (d) pengawasan yang ketat terhadap akhlak siswa di dalam maupun di luar sekolah; serta (e) 6\% guru alumni SMU Al Islam sendiri. Ketiga sekolah memiliki beberapa kesamaan antara lain: (1) setiap tahunnya jumlah siswa yang mendaftar, jauh lebih besar dibanding dengan jumlah yang diterima; (2) ketiga sekolah menekankan pada kedisiplinan; (3) ketiganya melakukan upaya serius untuk 
mengembangkan prestasi siswa dan sekolah sehingga mereka menjadi unggul.

Kedua, ragam nilai dalam budaya organisasi di masing-masing sekolah sebagai berikut: (I) nilai-nilai yang menonjol di SMU Negeri 1, Surakarta meliputi: (a) nilai keunggulan, (b) nilai prestasi dan persaingan, (c) nilai keefektifan, (d) nilai kedisiplinan, (e) nilai kemandirian, (f) nilai prestise; (2) pada SMU Regina Pacis Surakarta, yang nampak adalah (a) nilai dasar Kristiani, yaitu cinta kasih, (b) nilai dasar biara yaitu: kemurnian, kemiskinan dan ketaatan, (c) nilai utama Ordo Santa Ursula berupa nilai pengabdian, (d) nilai pelayanan, (e) nilai tanggung jawab, (f) nilai kualitas, (g) nilai ketertiban dan kedisiplinan, (h) nilai toleransi, (i) nilai keadilan dan kejujuran, serta (j) nilai prestise; (3) nilai-nilai yang nampak di SMU Al Islam 1, Surakarta, meliputi (a) nilai dasar ajaran Islam, yaitu tauhid; (b) nilai ibadah; (c) nilai integralitas antara dunia dan akhirat serta antara ilmu agama dan ilmu umum; (d) nilai perjuangan (jihad); (e) nilai tanggung jawab (amanah); (f) nilai keikhlasan; (g) nilai kualitas; (h) nilai kedisiplinan; (i) nilai keteladanan; (j) nilai persaudaran dan kekeluargaan; serta (k) nilai-nilai pesantren, yaitu: kesederhanaan atau kesahajaan, tawadlu' (rendah hati), dan kesabaran.

Ketiga, nilai dasar yang berpengaruh ada keunggulan masing-masing sekolah, (1) pada SMU Negeri 1 Surakarta, nilai dasar yang sangat berpengaruh adalah nilai keunggulan. knplikasinya adalah warga sekolah selalu menginginkan segalanya unggul, mulai dari siswa, guru, kepala sekolah, staf, orang tua siswa, komite sekolah, alumni dan bahkan pemerintah kota, (2) pada SMU Regina Pacis Surakarta, nilai dasar yang menjadikan keunggulan sekolah adalah nilai pengabdian dan pelayanan. Nilai ini dihayati sepenuhnya oleh para suster, baik pimpinan biara, pengurus yayasan, kepala sekolah maupun guru. Mereka memiliki komitmen total dan tanpa pamrih dalam mengelola sekolah, (3) pada SMU Al Islam 1, Surakarta, nilai dasar yang menjadikan sekolah ini unggul adalah nilai ibadah (pengabdian) dan amanah (tanggung jawab). Nilai ibadah sama esensinya dengan nilai pelayanan dan pengabdian pada SMU Regina Pacis, namun tingkat konsentrasi dalam memberikan pelayanan san pengabdian pada sekolah berbeda dengan para biarawanbiarawati. Nilai amanah berupa kesadaran bahwa semua pekerjaan merupakan amanah yang harus dipertanggungjawabkan kepada manusia dan kepada Tuhan.

Usa (2008) dalam penelitian disertasinya yang berjudul "Hubungan antara Gaya Kepemimpinan Kepala Sekolah, Budaya Organisasi, Iklim Organisasi, Kepuasan Kerja Guru dan Komitmen Guru dengan Kinerja Guru SMA Negeri di Kabupaten Buton dan Kota BauBau". Penelitian kuantitatif yang menggabungkan beberapa variabel, termasuk didalamnya variabel "budaya organisasi" dan "iklim organisasi" diteliti oleh Usa (2008) dalam penelitian disertasinya yang berjudul "Hubungan antara Gaya Kepemimpinan Kepala Sekolah, Budaya Organisasi, Iklim Organisasi, Kepuasan Kerja Guru dan Komitmen Guru SMA Negeri di Kabupaten Buton dan Kota Bau-Bau." Beberapa temuan penelitiannya antara lain menunjukkan bahwa (I) ada hubungan tidak langsung yang tidak signifikan antara gaya kepemimpinan kepala sekolah dengan iklim organisaisi melalui budaya organisasi, (2) ada hubungan tidak langsung yang signifikan antara gaya kepemimpinan kepala sekolah dengan kepuasan kerja guru melalui budaya organisasi dan iklim organisasi, (3) ada hubungan tidak langsung yang tidak signifikan antara budaya organisasi dengan kepuasan kerja guru melalui iklim organisasi, (4) ada hubungan tidak langsung yang signifikan antara gaya kepemimpinan kepala sekolah dengan komitmen guru melalui budaya organisasi, iklim organisasi, dan kepuasan kerja guru, (5) ada hubungan tidak langsung yang signifikan antara budaya organisasi dengan komitmen guru melalui iklim organisasi dan kepuasan kerja guru, (6) ada hubungan tidak langsung yang tidak signifikan antara iklim organisasi dengan komitmen guru melalui kepuasan kerja guru, (7) ada hubungan tidak langsung yang signifikan antara gaya kepemimpinan kepala sekolah dengan kinerja guru melalui budaya organisasi, iklim organisasi, kepuasan kerja guru, dan komitmen guru terhadap organisasi, (8) ada hubungan tidak langsung yang signifikan antara budaya organisasi dengan kinerja guru melalui iklim organisasi, kepuasan kerja guru, dan komitmen guru terhadap organisasi, dstnya. Dari penelitian ini Usa (2008) menyarankan agar hasil penelitian ini dapat diterapkan dalam kebijakan pembangunan dalam bidang pendidikan pada tingkat persekolahan.

Penelitian-penelitian diatas menunjukkan bahwa budaya organisasi maupun iklim 
organisasi dapat diukur dengan instrumen sebagaimana contoh pada lampiran.

\section{SIMPULAN DAN SARAN Simpulan}

Berdasarkan pembahasan tentang manajemen kultur sekolah di atas, maka daat disimpulkan hal-hal sebagai berikut :

1. Kultur (budaya) adalah nilai-nilai dominan yang didukung oleh organisasi. Setiap organisasi mempunyai kultur sendiri yang unik. Termasuk organisasi yang berbentuk lembaga pendidikan yaitu sekolah.

2. Kultur organisasi merupakan persepsi umum yang diyakini oleh para anggota organisasi.

Kultur tersebut telah ada sejak organisasi itu berdiri.

3. Beberapa unsur kultur organisasi antara lain: (a) adanya aturan penyeimbang yang tidak tertulis, (b) mempunyai bahasa sendiri dalam menjembatani komunikasi, (c) standarisasi aspek kerja yang berlaku, (d) standar yang berlaku didalam etika dan bertingkah laku, (e) penentuan kebiasaan membina hubungan seorang anggota dengan teman sebayanya, (f) bawahan, atasan dan pihak luar, dan (g) kebiasaan lain yang disesuaikan dengan kebiasaan pada umumnya.

4. Unsur-unsur tersebut di atas (no.3), apabila diterapkan dalam lingkungan sekolah banyak sekali persamaannya, yaitu: (a) adanya tata tertib di sekolah, (b) normanorma yang berlaku di sekolah dan (c) kebiasaan-kebiasaan di sekolah, dan sebagainya. Yang kesemuanya itu membentuk kultur suatu organisasi sekolah.

5. Karakteristik utama yang menjadi pembeda kultur organisasi adalah : (a) inisiatif individual, (b) toleransi terhadap tindakan berisiko, (c) arah, (d) integrasi, (e) dukungan dari manajemen, (f) kontrol, (g) identitas, (h) sistem imbalan, (i) toleransi terhadap konflik, dan (j) pola-pola komunikasi.

6. Kultur merupakan pandangan hidup yang diakui bersama oleh suatu kelompok masyarakat, yang mencakup cara berfikir, perilaku, sikap, nilai yang tercermin baik dalam ujud fisik maupun abstrak.

7. Kultur sekolah dalam suatu lingkungan pendidikan sangat dipengaruhi oleh kepemimpinan kepala sekolah. Kepala sekolah menempati posisi penting dalam merubah struktur sekolah, Perubahan kultur yang lebih sehat harus dimulai dari

8. Penelitian-penelitian tentang budaya organisasi yang telah dilaksanakan, baik tesis maupun disertasi oleh Soetopo (2001), Salfen (2002), Hariyanto (2002), Ekosusilo (2003), Gemnafle (2003), Usa (2008) menunjukkan bahwa ada hubungan yang signifikan antara budaya organisasi dengan kinerja guru, keterampilan manajerial kepala sekolah, pelaksanaan kepengawasan, iklim organisasi, keefektifan organisasi.

Saran

Berdasarkan simpulan di atas, maka dapatlah dikemukakan saran-saran sebagai

1. Sekolah akan lebih baik, apabila kepala sekolah: (a) berperan sebagai model, (b) mampu membangun tim kerjasama, (c) mau belajar dari guru, staf, dan siswa, dan (d) harus memahami kebiasaan yang baik untuk terus dikembangkan.

2. Kepala Sekolah dan guru harus mampu memahami lingkungan sekolah yang spesifik tersebut. Karena akan memberikan perspektif dan kerangka dasar untuk melihat, memahami dan memecahkan berbagai problem yang terjadi di sekolah. Dengan dapat memahami permasalahan yang kompleks sebagai suatu kesatuan secara mendalam, kepala sekolah dan guru akan memiliki nilai-nilai dan sikap yang amat diperlukan dalam menjaga dan memberikan lingkungan yang kondusif bagi berlangsungnya proses pendidikan.

3. Kepala sekolah menempati posisi yang penting dalam merubah struktur sekolah. Untuk melakukan peran dalam merubah kultur ini, kepala sekolah perlu memahami berbagai teori dan konsep dalam pendidikan.

4. Perlu dioptimalkan kondisi-kondisi yang dapat mendukung menjadi semakin mantapnya perwujudan kultur sekolah, antara lain adalah: (a) kepemimpinan, (b) keteladanan, dan (c) bimbingan terhadap setiap anggota agar mampu meningkatkan semangat kerja dan rasa bangga terhadap lembaganya.

\section{DAFTAR PUSTAKA}

Ekosusilo, M. 2003. Sistem Nilai dalam Budaya Organisasi pada Sekolah Unggul (Studi Multi Kasus di SMU Negeri 1, SMU Regina Pacis, dan SMU Al Islam I di Surakarta). Disertasi, tidak 
dipublikasikan. Malang: Program Studi

Manajemen Pendidikan, Program

Pascasarjana, Universitas Negeri Malang.

Gemnafle, M. 2003. Hubungan Budaya Organisasi, Keterampilan Manajerial Kepala Sekolah dan Pelaksanaan Pengawasan dengan Kinerja Guru dalam Mengajar SMU Negeri dan Swasta di Sulawesi Tenggara. Disertasi, tidak dipublikasikan. Malang: Program Studi Manajemen Pendidikan, Program Pascasarjana, Universitas Negeri Malang.

Gordon, J.R. 1991. A Diasnostic Approach to Organizational Behavior. $3 \mathrm{t}^{\mathrm{d}} . \mathrm{d}$. Needham Hights, Mass: Allyn and Bacon.

Hariyanto, H. 2002. Kontribusi Kinerja Kepala Sekolah dan Budaya Sekolah terhadap Kinerja Guru SLTP Negeri di Kabupaten Malang. Tesis, tidak dipublikasikan. Malang: Program Studi Manajemen Pendidikan, Program Pascasarjana, Universitas Negeri Malang.

Hasri, S. 2002. Budaya Organisasi Perguruan Tinggi: Studi di Sekolah Tinggi Ilmu Ekonomi (STIE) "Abdi Bangsa Indonesia". Disertasi, tidak dipublikasikan. Malang: Program Studi Manajemen Pendidikan, Program Pascasarjana, Universitas Negeri Malang.

Hersey, P., \& Blanchard, K.H. 1978. Management of Organizatioal Behavior: Utilizing Human Resources. 3nd edition. New Delhi: Prentice-Hall of India.

Indrapradja, F.X.T. 1992. Pemimpin dan Budaya Perusahaan. Jurnal Ilmu-Ilmu Sosial, Manajemen Konsensus dalam Bisnis 3. Jakarta: PT Gramedia Pustaka Utama.

Luthans, F. 1989. Organizational Behavior. $5^{\text {th.ed }}$ New York: McGraw-Hill, Inc.

Koentjaraning,rat. 1989. Kebudayaan, Mentalitas dan Pembangunan. Jakarta: Rineka Cita.

Koentjaraningrat. 1996. Pengantar Antroologi. Jilid 1. Jakarta: Rineka Cita.

Mastuhu. 2003. Menata Ulang Pemikiran Sistem Pendidikan Nasional dalam Abad 21 (The New Mind Set of National Education in the 21st Century).
Yogyakarta: Penerbit Safiria Insania Press bekerjasama dengan Magister Studi Islam Universitas Islam Indonesia.

Peraturan Pemerintah RI tentang Rencana Pembang,unan Jangka Menengah Nasional Tahun 2004-2009. Jakarta: Penerbit CV Tamita Utama.

Ouchi, W.G. 1981. Theory Z. New York: Addison-Wesley.

Owens, R.G. 1991. Organizational Behavior in Education. Fourth Edition. Boston: Allyn and Bacon.

Robbins, S.P. 1990. Teori Organisasi: Struktur, Desain \& Aplikasi. Edisi 3. Jakarta: Penerbit Arcan.

Soedomo. 1989/1990. Landasan Pendidikan. Malang: IKIP Malang.

Sonhadji, K.H.A. 1991. Birokrasi, Hubungan Manusiawi dan Budaya dalam Organisasi. Malang: IMP Malang.

Soetopo, H. 2001. Hubungan Karakteristik Bawahan, Kontrol Situasi, Perilaku Kepemimpinan, Budaya Organisasi, dan Iklim Organisasi dengan Keefektifan Organisasi pada Universitas Swasta di Kota Malang. Disertasi tidak dipublikaksikan. Malang: Program Studi Manajemen Pendidikan, Program Pascasarjana, Universitas Negeri Malang.

Suryaman. 2007. Budaya Organisasi Sekolah: Suatu Studi Etnografi. Malang: Surya Pna Gemilang.

Tirtarahardja, U. \& Sulo, S.L.L. 2005. Pengantar Pendidikan. Jakarta: Penerbit PT Rineka Cipta.

Usa, L.O. 2008. Hubungan antara Gaya Kepemimpinan Kepala Sekolah, Budaya Organisasi, Iklim Organisasi, Kepuasan Kerja Guru dan Komitmen Guru dengan Kinerja Guru SMA Negeri di Kabupaten Buton dan Kota Bau-Bau. Disertasi, tidak dipublikasikan. Malang: Progam Studi Manajemen Pendidikan. Progam Pascasarjana, Universitas Negeri Malang.

Williams, C. 2001. Manejemen. Terjemahan oleh M. Sabarudin Napitupulu. Jakarta: Penerbit Salemba Empat. 
